\title{
Michał Januszkiewicz
}

\section{Filozofia i literatura.} Komplikacje i transakcje

Philosophy and Literature. Complications and Transactions

\author{
Pamięci profesora Norberta Leśniewskiego, \\ wybitnego hermeneuty i Przyjaciela
}

\begin{abstract}
Abstrakt
Niniejszy artykuł omawia kwestie relacji między filozofią a literaturą, ich wzajemnych uwikłań, różnic i podobieństw. Celem tekstu jest namysł nad różnymi koncepcjami prezentującymi zależności między tymi dwoma dyskursami. Stanowisko pierwsze głosi odrębność filozofii i literatury, stanowisko drugie osłabia granice między nimi. Ten drugi pogląd ma swoje dwie wersje: jedna głosi osłabienie odrębności dyskursów w imię znaczenia czy wskazywanych sensów, druga zaś akcentuje ich wewnętrzne uwikłanie, które można by opisać w odniesieniu do dwóch zjawisk - literackości filozofii i filozoficzności literatury. Kolejnymi poruszanymi przez autora zagadnieniami są filozofia egzystencjalna jako szczególny przykład koincydencji literatury i filozofii oraz filozofia literatury jako dyscyplina eksponująca między innymi filozoficzność literatury oraz filozoficzno-metodologiczne podstawy jej badań. Interpretacji poddane zostały klasyczne dzieła Platona oraz innych filozofów starożytnej Grecji, prace Romana Ingardena,
\end{abstract}


Johna Austina, Tadeusza Komendanta, Alberta Camusa i Martina Heideggera. Analiza tych dzieł skonfrontowana została z lekturą takich pisarzy jak Fiodor Dostojewski, Franz Kafka, Herman Hesse, Witold Gombrowicz oraz Tadeusz Różewicz. Artykuł ma charakter teoretyczny i wpisuje się w dyscyplinę zwaną filozofią literatury. Autor przyjmuje w nim perspektywę hermeneutyczną, zaznaczając jednak, że hermeneutyka nie jest metodą w sensie ścisłym. Tekst stawia tezę o wzajemnym uwikłaniu dyskursu filozoficznego i literackiego, mimo że historycznie niejednokrotnie podkreślano odrębność tych dwóch porządków.

Słowa klucze: filozofia, literatura, egzystencjalizm, hermeneutyka, filozofia literatury

\begin{abstract}
This paper discusses the relationship between philosophy and literature, their mutual entanglements, differences and similarities. The aim of the article is to reflect on the different concepts presenting the relationship between these two discourses. The first position claims that philosophy and literature are separate, while the second one blurs the boundaries between them. The latter view has two versions: one that claims to diminish the separateness of the discourses in the name of meaning or indication, and another that accentuates their internal entanglement, which could be described in terms of two phenomena - the literary nature of philosophy and the philosophical nature of literature. Further issues discussed are existential philosophy as a special example of the coincidence of literature and philosophy, and the philosophy of literature as a discipline exposing, among other things, the philosophical nature of literature on top of the philosophical and methodological foundations of its studies. Classical works by Plato and other ancient Greek philosophers, the works of Roman Ingarden, John Austin, Tadeusz Komendant, Albert Camus, and Martin Heidegger are interpreted. The analysis of these works is confronted with the reading of such writers as Fyodor Dostoyevsky, Franz Kafka, Herman Hesse, Witold Gombrowicz and Tadeusz Różewicz. The article is a theoretical inquiry and fits into the discipline which is called the philosophy of literature. The author adopts a hermeneutical perspective, noting, however, that hermeneutics is not a method in the strict sense. The text posits that philosophical and literary discourse are mutually entangled, despite the fact that historically the separateness of the two orders has often been emphasized.
\end{abstract}

Keywords: philosophy, literature, existentialism, hermeneutics, philosophy of literature 
Literatura i filozofia to dwa odmienne dyskursy, których wzajemne relacje są skomplikowane. Zdanie to nie jest niewinne czy neutralne. Zakłada bowiem z góry możliwość, czy wręcz konieczność rozróżnienia między owymi dyskursami, a to rozróżnienie zdaje się możliwe szczególnie na gruncie przyjęcia jakiejś esencjalistycznej teorii filozofii i literatury, która byłaby zdolna trafnie wskazać charakteryzujące je atrybuty i niezmienniki. Innymi słowy przyjmuje się tu, że istnieje pewien określony sposób, w jaki wypowiada się filozofia i - analogicznie - że istnieje jakiś swoisty język, za pomocą którego wypowiada się literatura. Czy takie rozróżnienie rzeczywiście jest możliwe? Czy raczej nie rozpoznaliśmy faktu, że relacja między filozofią a literaturą jest dużo bardziej zawikłana, a komplikacje nie dotyczą wyraźnie dających się wskazać odrębności, lecz - przeciwnie - wzajemnych uwikłań, podobieństw, czy nawet punktów wspólnych, słowem: owocnych transakcji? Czy jednak oznaczałoby to, że powinniśmy zrezygnować z rozróżniania tych dwóch dyskursów?

Spróbujmy się przyjrzeć rozmaitym poglądom na ten temat. W sposób szczególny interesować mnie będą następujące kwestie:

1. stanowisko głoszące odrębność dyskursów - filozoficznego i literackiego;

2. stanowisko osłabiające granice między tymi dyskursami (ten pogląd ma swoje dwie wersje: jedna głosi osłabienie odrębności dyskursów w imię znaczenia czy wskazywanych sensów; druga zaś akcentuje ich wewnętrzne uwikłanie, które można by opisać w odniesieniu do dwóch zjawisk - literackości filozofii i filozoficzności literatury);

3. filozofia egzystencjalna jako swoisty przykład koincydencji literatury i filozofii;

4. filozofia literatury jako szczególna dyscyplina eksponująca między innymi filozoficzność literatury oraz filozoficzno-metodologiczne podstawy jej badań.

\section{Filozofia i literatura - odrębne światy}

Odrębności filozofii i literatury dowodzić by można już z historycznej perspektywy, jeśli sięgniemy do narodzin filozofii w VI wieku przed naszą erą. Na ogół uważa się, że pojawiła się ona jako odpowiedź na panujący dotąd mityczny obraz świata, którego cechą charakterystyczną było modelowanie go za pomocą obrazów, wyobraźni, uczuć. Tymczasem filozofia chciała się porządkowi temu przeciwstawić poprzez konstruowanie racjonalnego, to znaczy opartego na uzasadnianiu i wnioskowaniu, 
porządku świata. W ten sposób, można powiedzieć, stosunek filozofii do literatury okazuje się szczególnym wyrazem konfliktu pomiędzy logos i mythos. Ta oto opozycja wyznaczyła z kolei inne opozycje binarne: filozoficzne - przedfilozoficzne, logika - opowieść, nauka - sztuka, duch - uczucie (intuicja), męskie - kobiece. Przy czym w obszar mythos włącza się także, jak dzieje się to w psychologii Junga, eros (opozycja logos - eros).

Różnicę między mitem (literaturą) a logosem (filozofią) tak oto charakteryzuje Giovanni Reale:

Mit jest opowiadaniem o charakterze wyobrażeniowo-poetyckim, mającym zazwyczaj za przedmiot te same rzeczy [...], które bada filozofia. Także duch mitu jest podobny do ducha filozofii, gdyż mit jest bezinteresowny, czyli kontemplatywny, i rodzi się z tego samego zdziwienia, które jest źródłem filozofii. Różnica miedzy mitem a filozofią polega na tym, że filozofia posługuje się logosem i samym rozumem, a nie przedstawieniami wyobrażeniowo-poetyckimi ${ }^{1}$.

Jest sprawą bezsporną, że filozofia chciała zaproponować nie tylko alternatywny względem mitu sposób rozumienia rzeczywistości, ale także bardziej obiektywny i adekwatny niż obraz i wyobrażenie ogląd rzeczy. Radykalny rozdział między dyskursami filozoficznym i literackim podkreślać miały nie tylko odmienne sposoby postrzegania rzeczy, ale i stawiane cele. Filozofia odżegnywała się od literatury, bo ta miała skupiać się jedynie na wyobrażeniach (obrazach), podczas gdy ona dążyła do obiektywnego poznania. Filozofia usiłuje poznać prawdę, literatura gubi się w świecie fikcji. Odrębność tych dwóch światów dostrzega wyraźnie sofista Gorgiasz z Leontinoi. Za główny mechanizm literatury uznaje on apate (notabene mówić tu można o jednej z najstarszych koncepcji fikcji literackiej) - oszustwo. Literatura oznacza pakt między autorem i czytelnikiem, polegający na oszukiwaniu. Miarą literatury jest oszustwo, które czyni autor, i zgoda na bycie oszukiwanym wyrażona przez odbiorcę ${ }^{2}$. W gruncie rzeczy chodzi tu o to, że świat literatury to wymysł autora, a zgoda na bycie oszukanym to po prostu akceptacja dla istnienia świata zmyślonego (alternatywnego). Literatura, podobnie jak retoryka, nie ma nic wspólnego z poszukiwaniem prawdy ani czystym teoretycznym

1 Giovanni Reale, Historia filozofii starożytnej, t. V, tłum. Edward I. Zieliński, (Lublin: Wydawnictwo Katolickiego Uniwersytetu Lubelskiego, 2002), 134.

2 Vide: Gorgiasz, „Pochwała Heleny”, w Janina Gajda, Sofiści, tłum. Janina Gajda, (Warszawa: Wydawnictwo Wiedza Powszechna, 1989). 
widzeniem; celem jest wyłącznie poruszanie uczuć - mówi Gorgiasz. Poglądy greckiego sofisty stały się punktem odniesienia dla Platona, którego teoria idei zdaje między innymi sprawę z niechęci do sztuki (w tym także literatury) mimetycznej, która jedynie dba o zmysłowe odwzorowywanie rzeczywistości, a przez to prowadzi nas na manowce, gdyż zapoznaje to, co prawdziwe - duchowe, niezmienne, wieczne, inteligibilne. W zamian natomiast wciąga nas w to, co zmysłowe, widzialne, nietrwałe. Literatura odwodzi nas od prawdy - mówi Platon. Filozofia, w przeciwieństwie do literatury, posługuje się pojęciami, dąży do jednoznacznego definiowania rzeczy; literatura to świat metafor, „koślawych” pojęć. Z perspektywy logiki metafora jest niczym innym jak bełkotem ${ }^{3}$. Bełkot to wypowiedź, która nie jest przekładalna na wypowiedź jednoznaczną i „przezroczystą". Dla filozofii miarą prawdy jest rzeczywistość (to, co jest), a język traktuje ona jedynie jako pomocnicze i nieistotne narzędzie jej opisu, podczas gdy literatura nie dba o rzeczywistość, za to uprzywilejowuje język - metaforyczny, symboliczny, „nieprzezroczysty”. Filozofia zainteresowana jest faktami, literatura zaś to domena interpretacji, a więc języka.

\begin{tabular}{|c|c|}
\hline Filozofia (logos) & Literatura (mit) \\
\hline poznanie & wyobrażanie \\
\hline myślenie & zmyślenie \\
\hline prawda & fikcja \\
\hline pojęcia & metafory \\
\hline rzeczywistość & język \\
\hline fakty & interpretacje \\
\hline
\end{tabular}

Nie sposób jednak nie zauważyć, że choć mythos nie mógł posługiwać się narzędziami filozofii, to jednak nigdy nie rezygnował z zadawania pytań i wyjaśniania świata w filozoficzny sposób. Jeśli przyjrzymy się funkcjom mitów, to bez trudu odnajdziemy takie, które pokrywają się z głównymi obszarami filozofii. Gdy mit zapytuje o to, co i w jaki sposób istnieje, spełnia funkcję ontologiczną; gdy zapytuje o to, jak świat pozwala się poznać - funkcję epistemologiczną; gdy zajmuje się tym, co ważne i wyznaczające horyzont sensu - funkcję aksjologiczną; gdy wreszcie wyznacza to, co być powinno, i odpowiada na pytanie, jak żyć - spełnia funkcję etyczną.

3 Vide: Barbara Stanosz, „Bełkot i przesąd”; Henryk Hiż, „W obronie bełkotu”; Jacek Jadacki, „O bełkocie”. Wszystkie teksty w Język współczesnej humanistyki, red. Jerzy Pelc, (Warszawa: Polskie Towarzystwo Semiotyczne, 2000). 
Jeśli chodzi natomiast o grecką filozofię, to wcale nie jest tak, że całkowicie rezygnowała ona $z$ odwołań do poetyckich wyobrażeń i metafor. Wręcz przeciwnie. Już filozofia przedsokratejska (Tales z Miletu, Anaksymander, Anaksymenes, Heraklit, Parmenides) nader często utkana jest z poetyckiego języka. Warto przywołać tu na przykład pierwsze zdanie zapisane w greckiej filozofii, a pochodzące od Anaksymandra: „A z czego powstają istniejące rzeczy, w to niszczeją, „zgodnie z koniecznością: płacą bowiem sobie nawzajem karę i pokutę za niesprawiedliwość, zgodnie z postanowieniem Czasu"4. Zdanie to ma nie tylko poetycką formę, ale i religijny sens: mówi o początku zwiastującym koniec i o byciu ku śmierci, którego nie da się oderwać od winy, kary i pokuty.

Za pierwszego filozofa, który wprowadza filozofię do literatury, uznać należy innego presokratyka: Ksenofanesa $\mathrm{z}$ Kolofonu. To jedyny z filozofów presokratejskich posługujący się formą wierszowaną. Fakt ów nie jest wcale bez znaczenia, bo jak zauważa Adam Krokiewicz:

„wierszowana filozofia” zwracała się do wszystkich wykształconych Hellenów, a „filozofia prozaiczna” - do nielicznej grupy naukowców. Filozofię spopularyzowali poeci, przede wszystkim tragicy. Ajschylos, Sofokles i szczególnie Eurypides pozostawali pod silnym wpływem Ksenofanesa ${ }^{5}$.

Także Platon, wbrew deklaracjom (znanym choćby z Fajdrosa czy Protagorasa), chętnie korzysta $\mathrm{z}$ form poetyckich, można nawet powiedzieć, że podejmuje on próbę rehabilitacji mitu, ponieważ rozumie, że obraz i metaforę można efektywnie spożytkować dla celów filozoficznych. Dowodami mogą tu być metafora jaskini z siódmej części Państwa, metafora skrzydlatego zaprzęgu z Fajdrosa czy wreszcie dialog Timajos, osnuty na kanwie mitycznej.

Jak widać z powyższych przykładów, radykalne przeciwstawianie sobie dyskursów filozoficznego i literackiego budzić może wątpliwości. Mimo to ich historia niejednokrotnie zaświadcza o walce i sporze. Tak dzieje się choćby w ramach stanowiska pozytywistycznego, które wyraźnie odgraniczać będzie oba dyskursy, dowodząc, że chodzi tu nie tylko o różnice dotyczące środków wyrazu, ale i o to, że język filozoficzny, w przeciwieństwie do literackiego, posługując się pojęciami, odnosi się do świata rzeczy obiektywnych i realnych. Co interesujące, słynny antypozytywista i twórca filozofii literatury, Roman Ingarden, również

4 Geoffrey S. Kirk, John E. Raven, Malcolm Schofield, Filozofia przedsokratejska, tłum. Jacek Lang, (Warszawa-Poznań: PWN, 1999), 125.

5 Adam Krokiewicz, Zarys filozofii greckiej (Warszawa: Aletheia, 2000), 118. 
stoi na straży granic pomiędzy tymi dwoma dyskursami. Broni on także ich „czystości”. Zdaniem słynnego fenomenologa fundamentalna różnica pomiędzy wypowiedzią filozoficzną a literacką polega na tym, że pierwsza posługuje się zdaniami orzekającymi, to znaczy sądami w sensie logicznym, druga zaś - quasi-sądami ${ }^{6}$. O ile sądy orzekają coś na temat świata i w związku z tym są prawdziwościowo weryfikowalne, o tyle quasi-sądy ani niczego o świecie nie orzekają, ani nie poddają się podobnej weryfikacji. Koniecznie trzeba więc w tym miejscu podkreślić, że literacka fikcja (skonstruowana na quasi-sądach) nie może być pojmowana jako przeciwieństwo prawdy. W sensie logiki bowiem przeciwieństwem prawdy jest fałsz, a nie literacka fikcja. Ta ostatnia nie pozwala na to, by ujmować wypowiedź nie tylko jako prawdziwą, ale i fałszywą.

Podobną wymowę ma, jak się wydaje, teoria aktów mowy Johna L. Austina, który podzielił wypowiedzi na konstatywne i performatywne. Te pierwsze charakteryzuje referencja i odniesienia do świata - orzekanie; te drugie nie komunikują nam niczego o świecie, ale posiadają moc sprawczą: sama wypowiedź sprawia coś w świecie, przekształca go (jak akty obietnicy, formuły przyrzeczeń ślubnych czy słowa wypowiadane podczas chrzcin - „ja ciebie chrzczę"). Idąc za Austinem, uznać by można, że konstatywy charakterystyczne są dla wypowiedzi filozoficznej, performatywy zaś - dla poetyckiej (literackiej).

Pogląd wyraźnie rozgraniczający dyskursy filozoficzny i literacki z jednej strony poszukuje mocnych, ujmowanych esencjalistycznie podstaw formalnych $\mathrm{w}$ różnicach sposobów mówienia, struktury wypowiedzi. To dwa całkowicie odmienne i nieprzystające do siebie języki. Gatunkiem właściwym dla wypowiedzi filozoficznej jest traktat filozoficzny lub polemika, podczas gdy literatura wypowiada się w rozmaitych gatunkach literackich, jak poemat czy powieść. Z drugiej strony, o czym była już mowa, podkreśla radykalnie odmienne cele filozofii i literatury.

\section{Interferencje i transakcje albo osłabianie granic}

Sprawa jest jednak dużo bardziej złożona, niż może się wydawać zwolennikom zero-jedynkowych podziałów. Co ciekawe, w sukurs stojącym na stanowisku, które opowiada się za osłabieniem granic między dyskursami, przychodzi sam Arystoteles, którego passus z Poetyki dotyczący

6 Vide: Roman Ingarden, „O różnych rozumieniach "prawdziwości« w dziele sztuki” oraz „O tak zwanej prawdzie w literaturze. Czy zdania twierdzące w dziele sztuki literackiej są sądami »sensu stricto «"? Oba teksty w idem, Szkice z filozofii literatury (Kraków: Wydawnictwo Znak, 2000). 
filozofii, literatury i historii jest dobrze znany. Mówi więc Stagiryta, że w przeciwieństwie do historii, koncentrującej się na tym, co faktycznie było, odmienną drogą podążają filozofia i literatura, poszukujące prawdy o wymiarze ogólnym ${ }^{7}$. A zatem: filozofia i literatura nie tylko są sobie bliskie, ale nie można odmówić literaturze, jak czynią to zwolennicy odgraniczenia tych dyskursów, poszukiwania prawdy!

Chciałbym w tym miejscu wyróżnić dwa sposoby osłabiania granic między filozofią a literaturą. Pierwszy z nich abstrahuje od sposobów mówienia, które w sposób swoisty przysługują tym dwóm obszarom, uwypukla natomiast to, co między nimi wspólne - znaczenie. Taką propozycję formułuje na przykład Tadeusz Komendant, który w opozycji do metody pozytywistycznej, ostro oddzielającej filozofię i literaturę, wskazuje na metodę egzystencjalną, która

równouprawnia wypowiedzi filozoficzno-literackie, nie czyni jakościowych różnic między nimi. [...] znamienne dla tej metody jest pojęcie zna czenia: wypowiedź literacka i wypowiedź filozoficzna może znaczyć to samo, wybór między nimi nie jest istotny z punktu widzenia przekazywanych treści, lecz zależy tylko od strategii pisarskiej, dlatego, że obie są ekspresją - wyrazem twórczej świadomości ${ }^{8}$.

Prezentowane przez Komendanta stanowisko wydać się może zrazu kontrowersyjne: czy rzeczywiście wolno nam abstrahować od formy wypowiedzi na rzecz uprzywilejowania jej znaczenia? To pytanie do teoretyków filozofii literatury i twórców teorii literatury. Nie sposób jednak nie zauważyć, że metoda, o której mówi Komendant, faktycznie bywa świadomie praktykowana, czego najlepszym dowodem są egzystencjaliści tacy jak Jean-Paul Sartre czy Albert Camus. W podobnym duchu wypowiadają się Marian Przełęcki czy Katarzyna Rosner, którzy również dostrzegają więź między filozofią a literaturą, wyrażającą się we wspólnej funkcji poznawczej9.

7 Vide: Arystoteles, Poetyka, tłum. Henryk Podbielski, (Wrocław: Wydawnictwo Ossolineum, 1983), 26.

8 Tadeusz Komendant, „»Rycerz, śmierć i diabeł« (Literatura i filozofia dziś)”, w Wypowiedź literacka a wypowiedź filozoficzna, red. Michał Głowiński, Janusz Sławiński, (Wrocław: Wydawnictwo Ossolineum, 1982), 114.

9 Marian Przełęcki, „Wartość poznawcza wypowiedzi literackich i filozoficznych”, w Wypowiedź literacka a wypowiedź filozoficzna, red. Michał Głowiński, Janusz Sławiński, (Wrocław: Wydawnictwo Ossolineum, 1982), 9-25; Katarzyna Rosner, „Świat przedstawiony a funkcja poznawcza dzieła literackiego”, w Problemy teorii literatury, t. II, red. Henryk Markiewicz, (Wrocław: Wydawnictwo Ossolineum, 1987). W tej sprawie 
O ile pierwszy ze sposobów osłabiania granic abstrahuje od formy, a uprzywilejowuje znaczenie, to drugi zdaje się jego odwrotnością: skupia się bowiem na formalnych aspektach języka. Nie chodzi tu o kwestionowanie różnic w gatunkach wypowiedzi, lecz o rozpoznanie, które zawdzięczamy Martinowi Heideggerowi, że myślenie poetyckie to właśnie myślenie par excellence ${ }^{10}$ czy Derridiańskiej dekonstrukcji binarnych opozycji. Literatura i filozofia to już nie przeciwieństwa, ale zjawiska wzajemnie w siebie zawikłane, interferujące, transaktywne. Innymi słowy: mówić zasadnie możemy zarówno o filozoficzności literatury, jak i o literackich mechanizmach filozofii. Warto pamiętać, że jeśli mówimy o filozoficzności literatury, to nie tylko, a może w ogóle nie dlatego, że dany pisarz posługuje się myślą filozoficzną jako tezą, którą postanawia wkleić w literacką tkankę. Literatura nie jest więc filozoficzna wtedy, gdy filozofia pojawia się tu jedynie jako ilustracja czy funkcjonalny kontekst. Gdy tak się dzieje, dostrzegamy w literaturze zanik literackości i znajdujemy się w obszarze tego, co nazwano kiedyś literaturą (powieścią) z tezą. Literatura, aby być filozoficzną, nie może bowiem - choć paradoksalnie to zabrzmi - przestać być literaturą. Filozoficzność literatury nie może abstrahować od formy artystycznej czy języka poetyckiego. Śmiało można zaryzykować stwierdzenie, że każda wielka literatura jest literaturą filozoficzną, bo na gruncie swoistego języka usiłuje wypowiedzieć to, co ważne: poszukuje prawdy o człowieku i jego tożsamości, usiłuje nazywać to, co ważne (wartości) i próbować na różne sposoby odpowiadać na pytanie o to, jak żyć i radzić sobie w świecie. Przy czym wielka literatura, pozostając wierna swemu językowi, nie daje nigdy jednoznacznych i „przezroczystych” odpowiedzi, nie chce być i być nie może poradnikiem życiowym. Poszukując sensu, ukazuje raczej pogmatwane i pokręcone ścieżki ludzkiej egzystencji, podkreśla sprzeczności, uwypukla komplikacje. Zarazem: fikcja literacka nie jest tym, co odrywa nas od świata, przenosząc w obszar autorskiego „zmyślenia”, lecz wyznacza już zawsze horyzont naszego rozumienia i doświadczania świata.

Ale i filozofia nie jest wolna od literackich mechanizmów. I nie chodzi tu tylko o to, że niejednokrotnie posługuje się metaforami. Chodzi raczej o co innego: czy „opis” filozoficzny jest rzeczywiście - jak chciałby Przełęcki - „abstrakcyjnym opisem świata rzeczywistego"? ${ }^{11}$ Czy

vide: również: Michał Januszkiewicz, „Prawda i literatura”, w idem, Kim jestem ja, kim jesteś ty? Etyka, tożsamość, rozumienie (Poznań: Wydawnictwo Poznańskie, 2012).

10 Martin Heidegger, Co zwie się myśleniem?, tłum. Janusz Mizera, (Warszawa: Aletheia, 2000).

11 Przełęcki, Wartość poznawcza..., 21. 
kontrowersyjne nie jest już samo pojęcie rzeczywistości? Czy nie jest ona bowiem zawsze zinterpretowana podług rozmaitych założeń i celów? Czy zatem język filozoficzny jest językiem „przezroczystym”? A jeżeli filozofii „rzeczywistość” nie udostępnia się w sposób bezpośredni, to czy problemy filozoficzne nie są problemami języka, bez którego rozumienie i poznanie nie są możliwe? Język nie jest jedynie domeną literatury okazuje się również fundamentalnym problemem filozofii - zrozumieliśmy to już dawno na gruncie zwrotu lingwistycznego. Różnica między filozoficznym i obiektywnym opisem a literacką interpretacją nie może być dłużej utrzymana - filozofia także interpretuje świat. Nie istnieje w związku z tym także radykalna różnica pomiędzy filozoficznym poznaniem a poetyckim wyobrażeniem - jeśli tylko zgodzimy się, że operacje poznawcze nie mają charakteru neutralnego („przezroczystego”), tylko stanowią podmiotowe interpretacje, by nie powiedzieć - konstrukcje.

Trzeba tu wszakże podkreślić jedno: w przeciwieństwie do podejścia pierwszego, które pragnie niwelować różnice między filozofią i literaturą w imię wspólnoty znaczenia, w tym przypadku nie chodzi już o zniesienie różnic między filozofią a literaturą, którego konsekwencją byłby wniosek, że wszystko jest literaturą albo że wszystko jest filozofią. Chodzi raczej o pokazanie wzajemnego uwikłania tych dyskursów, zwrócenie uwagi na pewne analogiczne mechanizmy językowe czy narracyjne.

\section{Egzystencjalizm jako miejsce spotkania filozofii i literatury}

Wyróżnionym przykładem spotkania między filozofią i literaturą jest szeroko rozumiany egzystencjalizm. Zgoda, można w tym miejscu argumentować, że miejsc spotkań pomiędzy filozofią a literaturą jest znacznie więcej (choćby Derridiańska dekonstrukcja czy rozmaite zwroty w humanistyce); nie trzeba też nawet dodawać, że istnieją swoiście filozoficzno-literackie gatunki, jakimi są esej i powiastka filozoficzna, nader chętnie uprawiane, na przykład przez Woltera czy Leszka Kołakowskiego - trudno temu zaprzeczyć. Temat to bowiem bardzo szeroki. Można też zastanawiać się nad tym, jaki jest sens powrotu do egzystencjalizmu - czy nie jest to filozofia przebrzmiała i historycznie zamknięta, to znaczy wyczerpana w zakresie postawienia pewnych pytań i problemów? W pewnym sensie tak jest. Zwłaszcza wtedy, gdy spojrzymy na egzystencjalizm w perspektywie historycznej, która umożliwia nam wyznaczenie czasu oddziaływania tej filozofii od lat czterdziestych dziewiętnastego wieku (Kierkegaard, Dostojewski) do lat sześćdziesiątych dwudziestego wieku. 
Na egzystencjalizm możemy jednak spojrzeć szerzej - jako swoistą philosophia perennis, filozofię wymykającą się historycznym ramom. Tak pojęta, od zawsze (Sokrates, św. Augustyn, Mistrz Eckhart, Blaise Pascal, Schopenhauer, Nietzsche i inni) koncentruje się ona na człowieku, nie abstrakcyjnym czy modelowym, ale na tym, co można by nazwać kondycją ludzką w jej rozmaitych przypadłościach egzystencjalnych. Filozofia egzystencji nie pyta więc o to, kim jest człowiek jako taki, albo o to, czym jest natura ludzka, lecz usiłuje rozpatrywać egzystencję w jej stawaniu się, niekończącym projektowaniu czy sytuacjach granicznych. Egzystencjalizm proponuje więc dramatyczną koncepcję człowieka - dramatyczną w dwóch znaczeniach: po pierwsze, w jej nieustannym dialogu i sporze ze światem i z innymi oraz, po drugie, $w$ jej egzystencjalnym uwikłaniu, tragizmie i absurdzie; w jej poszukiwaniu, odnajdywaniu i gubieniu sensu.

Dlaczego jednak egzystencjalizm uznać możemy za szczególną formę spotkania filozofii i literatury? Jest tak przynajmniej z dwóch powodów. Po pierwsze, egzystencjalizm okazuje się rebelią dokonaną w łonie filozofii akademickiej, dążącej do metafizycznego, to znaczy systemowego i opartego na logice, sposobu uporządkowania i zorganizowania świata. Staje się on przeto wewnątrzfilozoficzną krytyką filozoficznego dyskursu, krytyką pojęć, które stały się wyrazem abstrakcji i czystej spekulacji, odwodzących myślenie od życia (bezpośrednią poprzedniczką egzystencjalizmu jest w końcu Lebensphilosophie) i konkretnej egzystencji - co pokazuje Kierkegaard w swej krytyce Hegla. Owa krytyka filozofii we wnętrzu filozofii przekłada się niejednokrotnie na kształt dyskursu, który formalnie, to znaczy pod względem językowym, zwraca się w stronę literatury. Swoistą literackość szeroko pojętego egzystencjalizmu odnajdujemy właśnie w jego literackich formach. Są to przede wszystkim narracja (pierwszo- i trzecioosobowa), stylizacja na list, styl aforystyczny w konwencji stylistycznej oraz esej czy dziennik w konwencji gatunkowej. Wszystkie te formy odnajdziemy u Sørena Kierkegaarda, ojca egzystencjalizmu - by wymienić tu przede wszystkim dzieła takie jak Albo-albo czy Bojaźń i drżenie. Aforystyczną formę stosowali także Blaise Pascal, uchodzący za jednego z głównych prekursorów filozofii egzystencji (Myśli), Artur Schopenhauer w Świecie jako woli i przedstawieniu czy w Aforyzmach o mądrości życia, Fryderyk Nietzsche - w całej swojej twórczości, czy wreszcie Emil Cioran. Stosowane konwencje stylistyczne i gatunkowe były u egzystencjalistów wyraźnym ukłonem w stronę dyskursu literackiego. Jeszcze wyraźniej literacki wymiar tej filozofii zaznaczyli francuscy egzystencjaliści - Jean-Paul Sartre i Albert Camus. Obaj celowali w twórczości prozatorskiej i dramatycznej. Nie sposób zrozumieć egzystencjalizmu bez Sartre’owskich Mdłości, Dróg 
wolności, zbioru opowiadań Mur czy dramatu Przy drzwiach zamkniętych; wiedza o egzystencjalizmie byłaby też niepełna, gdyby abstrahować od Camusowskich powieści Dżuma, Obcy czy Upadek. O ile Sartre aktywnie uprawiał także trudny fenomenologiczny żargon (Wyobrażenie, Byt i nicość), o tyle już jednak Albert Camus właściwie nie opuszczał terenu literatury - mam tu na myśli jego zbiory eseistyczne Mit Syzyfa oraz Człowiek zbuntowany, gdzie rozróżnienie między stylem i myśleniem filozoficznym a stylem i myśleniem literackim jest po prostu niemożliwe. Przyjrzyjmy się pierwszym zdaniom wypowiedzianym przez Camusa w pierwszym eseju z cyklu Mit Syzyfa:

Jest tylko jeden problem filozoficzny prawdziwie poważny: samobójstwo. Orzec, czy życie jest, czy nie jest warte trudu, by je przeżyć, to odpowiedzieć na fundamentalne pytanie filozofii ${ }^{12}$.

Zaryzykuję twierdzenie, że to kluczowe zdania wypowiedziane w filozofii Camusa. Mowa w nich dwukrotnie o filozofii: z perspektywy jej najważniejszego problemu i z perspektywy fundamentalnego pytania. Czy w ten sposób pisze jednak filozof akademicki? Czy filozof akademicki - zobligowany wewnętrznym nakazem krytycyzmu i poszukiwania prawdy obiektywnej, może napisać takie zdania? Camus jawi się tutaj jako pisarz: jest apodyktyczny, radykalny i, wydawałoby się, niedialogiczny: ",jest tylko jeden problem”, ,jest tylko jedna odpowiedź, jest tylko jedno fundamentalne pytanie. Wszystko inne (jak ilość kategorii czy obroty ciał niebieskich) jest nieistotne, wszystko inne to gry i zabawy. Można się nimi zająć później. Najpierw trzeba jednak odpowiedzieć na to jedno fundamentalne pytanie.

Jeżeli Camus formułuje swą wypowiedź w ten, a nie inny sposób, to prawo do tego daje mu jednak nie filozofia, ale literatura. Bo literatura, jak zauważył to już kiedyś Jacques Derrida, to taka instytucja, która daje prawo do powiedzenia wszystkiego ${ }^{13}$. Dlatego wszelkie możliwe filozoficzne polemiki z tą wypowiedzią, które mogłyby kwestionować jej apodyktyczność czy postawiony problem (czyżby naprawdę nie było ważniejszych filozoficznych zagadnień? A co z arche? A eidos? A co z hierarchią bytów?) są naprawdę nieistotne. Wypowiedź Camusa jest literacka także z uwagi na jej oddziaływanie: jest wyraźnie retoryczna, jest perswazyjna. Jest

12 Albert Camus, „Absurd i samobójstwo”, w idem, Eseje, wybór i tłum. Joanna Guze, (Warszawa: Państwowy Instytut Wydawniczy, 1971), 91.

13 Vide: Jacques Derrida, „Ta dziwna instytucja zwana literaturą. Wywiad z Derekiem Attridge’em", tłum. Michał P. Markowski, Literatura na świecie 11-12 (1988): 176-225. 
radykalna i dlatego - zgodnie z zarówno retorycznymi, jak i literackimi celami - poruszająca (movere) i zachwycająca (delectare). Zarazem: chce nas nauczyć (docere) czegoś naprawdę ważnego - konieczności poszukiwania Sensu, w którym kryje się ta najważniejsza z odpowiedzi na fundamentalne pytanie: czy życie jest, czy nie jest warte trudu, aby je przeżyć?

W tym miejscu zauważmy: ten filozoficzny i fundamentalny dylemat ustanowiony apodyktycznie przez prawo, jakie przychodzi od strony literatury jako instytucji, jest przecież zarazem fundamentalnym problemem wypowiedzianym w literaturze. A dzieje się tak za sprawą Szekspirowskiego Hamleta i jego „być albo nie być - oto jest pytanie!”. Filozof Camus jest pisarzem. Czy bywa jednak na odwrót - że pisarz może być zarazem filozofem? Odpowiedź na to pytanie w kontekście filozofii egzystencji jest oczywista. W wydanej wiele lat temu słynnej antologii egzystencjalizmu Walter Kaufmann rozpoczyna od... Dostojewskiego, a tytuł tej antologii to Existentialism from Dostoevsky to Sartre (1956) ${ }^{14}$. W trzy lata później niemiecki filozof wydaje z kolei książkę From Shakespeare to Existentialism (1959). A więc Szekspir, a więc Dostojewski. I wśród nich wielu innych, jak Franz Kafka, Hermann Hesse, Louis-Ferdinand Céline, ruch młodych gniewnych z Johnem Osbornem, Witkacy, Witold Gombrowicz, Tadeusz Różewicz, a dziś - najważniejszy przedstawiciel późnego egzystencjalizmu - Michel Houellebecq.

Trudno w tym miejscu zapomnieć o innej, poza literaturą, sztuce, która w sposób pełnoprawny uznawana być może za egzystencjalistyczną - to film: polska szkoła filmowa i kino moralnego niepokoju z Krzysztofem Kieślowskim na czele czy filmy Ingmara Bergmanna. Co decyduje o tym, że pisarza możemy nazwać filozofem? Z pewnością nie to, że uprawia on dyskurs przyjęty przez filozofię akademicką. Filozoficzny wymiar twórczości literackiej dochodzi do głosu zarówno w eksplicytnych, stematyzowanych odwołaniach do filozofii - jak dzieje się to w powieści Johna Waina Mniejsze niebo, gdzie bohater czyta eseje Camusa - jak i przede wszystkim wtedy, gdy stawia ona ważne pytania i problemy. Filozoficzna rebelia egzystencjalizmu, egzystencjalistyczna krytyka filozofii, okazuje się zatem akcesem do świata literatury, który staje się z kolei obszarem filozoficznego zwrotu, dokonującego się za pośrednictwem literackiego języka.

Drugi z powodów, dla których filozofia i literatura spotykają się w egzystencjalizmie, to - w konsekwencji - wspólnota problemów i tematów. $\mathrm{W}$ ich centrum odnajdujemy właśnie fundamentalny dylemat Camusa

14 Walter Kaufmann, Existentialism from Dostoevsky to Sartre (Cleveland and New York: New American Library, 1968); idem, From Shakespeare to Existentialism (Princeton: Princeton University Press, 1980). 
i Szekspira z jego pochodnymi: czym jest bycie? Kim jestem? Jaki jest sens mojego istnienia? Co to znaczy, że człowiek jest wolny? Czym jest bycie wobec innego? W zakres stawianych pytań wchodzi tu także etyka autentyczności ${ }^{15}$. Zarówno w filozofii egzystencji, jak i w egzystencjalnej literaturze problemem centralnym jest przecież poszukiwanie prawdy, ale nie prawdy w klasycznym, korespondencyjnym rozumieniu, lecz takiej - jak pokazał to po raz pierwszy Kierkegaard - której racją jest subiektywnośćc ${ }^{16}$. Nie chodzi tu przy tym o subiektywność rozumianą jako solipsyzm, samowolę sądów i ocen, niekomunikowalność czy po prostu wypaczoną formę indywidualizmu. Chodzi raczej o to, by pokazać człowieka jako byt niepowtarzalny, konkretny, jedyny i niezastępowalny. Człowiek tak pojęty zobowiązany jest do poszukiwania prawdy, która go osobiście obchodzi i za którą gotów by nawet oddać życie ${ }^{17}$.

\section{Filozofia literatury jako miejsce spotkania filozofii i literatury}

$\mathrm{Na}$ koniec warto poświęcić parę uwag humanistycznej dyscyplinie, której zadaniem jest namysł nad szeroko pojętymi relacjami między filozofią a literaturą. Tą dyscypliną jest filozofia literatury, a jej twórcą Roman Ingarden, zdaniem którego dyscyplina ta kieruje nas na najwyższy poziom wiedzy o literaturze ${ }^{18}$. Ujmując rzecz najogólniej: filozofia literatury sprowadzona zostaje przez Ingardena zasadniczo do ontologii dzieła literackiego, choć w tym kontekście wymienia on również (w tomie I Studiów z estetyki) inne działy: teorię poznania dzieła literackiego, estetykę literacką, filozofię twórczości literackiej czy socjologię literatury. Pogląd Ingardenowski można w sposób istotny rozwinąć o cały szereg innych ważnych kwestii dotyczących przede wszystkim filozoficznych podstaw teorii literatury i metodologii badań literackich, problematyki relacji między filozofią a literaturą (pojęcie-metafora, prawda-fikcja, poznanie-rozumienie i tym podobne), spraw takich jak literackość

15 Charles Taylor, Etyka autentyczności, tłum. Andrzej Pawelec, (Kraków: Wydawnictwo Znak, 2002); Martin Heidegger, Bycie i czas, tłum. Bogdan Baran, (Warszawa: PWN, 1994).

16 Søren Kierkegaard, Nienaukowe zamykajace post scriptum, tłum. Karol Toeplitz, (Kęty: Wydawnictwo Marek Derewiecki, 2011).

17 Albert Camus zauważył, że nikt nie będzie umierać za dowód ontologiczny czy jakąkolwiek prawdę naukową. Vide: Camus, Eseje, 91.

18 Vide: Roman Ingarden, Studia z estetyki, t. I, (Warszawa: PWN, 1957). 
filozoficzna i filozofia literacka, obecność filozofii w literaturze i literatury w filozofii, aksjologia literatury czy etyka literacko-filozoficzna.

Wśród twórców filozofii literatury w Polsce wymienić trzeba również Zygmunta Łempickiego (1886-1943), pomysłodawcę koncepcji „poetyki czystej", badacza silnie zainspirowanego myślą filozoficzną (na przykład Wilhelma Diltheya). To właśnie o nim powiada Ingarden, że należał do niewielu polskich historyków literatury, którzy poszukiwali filozoficznych podstaw literaturoznawstwa. Ingarden zauważył również, że dzieło Łempickiego okazało się zbyt trudne dla ówczesnych badaczy literatury, gdyż Łempicki odwoływał się do problematyki filozoficznej obcej polonistom, którzy najczęściej nie posiadali filozoficznych kompetencji.

Wśród zasadniczych problemów filozofii literatury obok tych, nad którymi skupił się Ingarden, wymienić można także i te, na które zwraca uwagę Christopher New w Philosophy of Literature. An Introduction ${ }^{19}$. Jego zdaniem filozofia literatury powinna koncentrować się na zagadnieniach takich jak namysł nad literackością (czym jest literatura?), wyobraźnią twórczą, metaforą, interpretacją i problemem intencjonalności znaczenia tekstu. Osobnymi kwestiami są zagadnienia dotyczące filozofów piszących o literaturze i pisarzy uprawiających filozofię.

Z badań filozoficzno-literackich wynika wyraźnie, że literatura nie jest dyskursem w sposób ostry przeciwstawnym filozofii, ale sama stanowi istotny wkład w filozofię i jej działy takie jak choćby aksjologia czy etyka, aczkolwiek prawdą jest, że literatura nie czyni tego w sposób pojęciowy i usystematyzowany, lecz swoistymi dla siebie środkami. Dowodem nierozerwalnego związku między filozofią a literaturą mogą być badania prowadzone na gruncie rozmaitych zwrotów badawczych, takich jak zwrot lingwistyczny, etyczny, narratywistyczny (pozwalają się one interpretować jako obszary filozofii literatury).

Jak można zasadnie sądzić, szczególnym wymiarem filozofii literatury jest hermeneutyka literacka (hermeneutyka egzystencjalna), która w sposób nierozerwalny wiąże literaturę z filozofią fenomenologiczno-hermeneutyczną. Fenomenologia hermeneutyczna (Martin Heidegger, Hans-Georg Gadamer, Paul Ricœur) nie jest metodologią w ścisłym sensie, ale obszarem umożliwiającym namysł nad literaturą i tym, co ma dla niej znaczenie fundamentalne: uwikłaną w świat egzystencją poszukującą sensu bycia. Hermeneutyka literacka byłaby więc szczególnego rodzaju antropologią ${ }^{20}$ : dzieło literackie coś nam mówi i daje nam do

19 Vide: Christopher New, Philosophy of Literature. An Introduction (London-New York: Routledge, 1999).

20 Chodzi tu o antropologię nie w rozumieniu antropologii kultury, ale o antropologię egzystencjalną w rozumieniu Wolfganga Isera i Michała P. Markowskiego. Vide: 
myślenia jako pewna interpretacja świata. Nie jest ono ujmowane tu ani jako autonomiczny wytwór artystyczny, ani jako fakt socjologiczny, ale jest zawsze zrelatywizowane do odbiorcy (interpretatora) na sposób egzystencjalny. Człowiekowi zasadniczo brak bezpośredniego dostępu do samego siebie - literatura jest więc szczególną mediacją pomiędzy zinterpretowanym w niej światem a odbiorcą, który sam zmuszony zostaje do interpretacji. Jak zauważa Paul Ricœur: rozumiemy siebie w obliczu tekstó ${ }^{21}$. Rozumienie literatury jest zawsze samorozumieniem.

\section{Podsumowanie}

Relacje między filozofią a literaturą należą do najbardziej pasjonujących zagadnień humanistyki. Obszary te, niejednokrotnie sobie w historii przeciwstawiane, $w$ istocie spotykają się ze sobą, interferują i dokonują między sobą ważkich kulturowo „transakcji”. Czasem żyją z sobą w niezgodzie, innym razem bywają po prostu komplementarne, wreszcie potrafią też tworzyć wspólny dyskurs. Literatura jest czymś, co ożywia filozofię, a zarazem sama jest bez niej nie do pomyślenia. Filozofia nie jest dla literatury po prostu kontekstem. Pojęcie kontekstu odnosi się przecież zawsze do czegoś zewnętrznego i suplementarnego. Filozofia jest istotnym wymiarem literatury, która na gruncie swoistego zmetaforyzowanego języka stawia pytanie o to, co najważniejsze - o sens: czy życie warte jest trudu, aby je przeżyć?

\section{Bibliografia}

\section{Książki i monografie}

Arystoteles, Poetyka, tłum. Henryk Podbielski, (Wrocław: Wydawnictwo Ossolineum, 1983).

Between Suspicion and Sympathy. Paul Ricoeur's Unstable Equilibrium, ed. Andrzej Wierciński, (Toronto: Hermeneutic Press, 2003).

Wolfgang Iser, „Towards A Literary Anthropology”, w idem, Prospecting. From Reader Response to Literary Anthropology (Baltimore: The Johns Hopkins University Press, 1989); Michał P. Markowski, „Antropologia i literatura”, Teksty Drugie 6 (2007).

21 Vide: Andrzej Wierciński, „Hermeneutics and the Indirect Path to Understanding”, $\mathrm{w}$ The Task of Interpretation. Hermeneutics, Psychoanalysis, and Literary Studies, ed. Dariusz Skórczewski, Andrzej Wierciński, Edward Fiała, (Lublin: Wydawnictwo KUL, 2009); Andrzej Wierciński, „Celebrating the Confusion of Voices and the Fusion of Hermeneutic Horizons", w Between Suspicion and Sympathy. Paul Ricoeur'sUnstable Equilibrium, ed. Andrzej Wierciński, (Toronto: Hermeneutic Press, 2003). 
Camus Albert, Eseje, wybór i tłum. Joanna Guze, (Warszawa: Państwowy Instytut Wydawniczy, 1971).

Charles Taylor, Etyka autentyczności, tłum. Andrzej Pawelec, (Kraków: Wydawnictwo Znak, 2002).

Heidegger Martin, Co zwie się myśleniem?, tłum. Janusz Mizera, (Warszawa: Aletheia, 2000).

Heidegger Martin, Bycie i czas, tłum. Bogdan Baran, (Warszawa: PWN, 1994).

Ingarden Roman, Szkice z filozofii literatury (Kraków: Wydawnictwo Znak, 2000).

Januszkiewicz Michał, „Prawda i literatura”, w Michał Januszkiewicz, Kim jestem ja, kim jesteś ty? Etyka, tożsamość, rozumienie (Poznań: Wydawnictwo Poznańskie, 2012), 88-110.

Kaufmann Walter, Existentialism from Dostoevsky to Sartre (Cleveland and New York: New American Library, 1968).

Kaufmann Walter, From Shakespeare to Existentialism (Princeton: Princeton University Press, 1980).

Kierkegaard Søren, Nienaukowe zamykające post scriptum, tłum. Karol Toeplitz, (Kęty: Wydawnictwo Marek Derewiecki, 2011).

Kirk Geoffrey S., Raven John E., Schofield Malcolm, Filozofia przedsokratejska, tłum. Jacek Lang, (Warszawa-Poznań: PWN, 1999).

Krokiewicz Adam, Zarys filozofii greckiej (Warszawa: Aletheia, 2000).

New Christopher, Philosophy of Literature. An Introduction (London, New York: Routledge, 1999).

Pelc Jerzy (red.), Język współczesnej humanistyki, (Warszawa: Polskie Towarzystwo Semiotyczne, 2000).

Reale Giovanni, Historia filozofii starożytnej, t. V, tłum. Edward I. Zieliński, (Lublin: Wydawnictwo Katolickiego Uniwersytetu Lubelskiego, 2002).

Rosner Katarzyna, „Świat przedstawiony a funkcja poznawcza dzieła literackiego", w Problemy teorii literatury, t. II, red. Henryk Markiewicz, (Wrocław: Wydawnictwo Ossolineum, 1987), 79-100.

The Task of Interpretation. Hermeneutics, Psychoanalysis, and Literary Studies, ed. Dariusz Skórczewski, Andrzej Wierciński, Edward Fiała, (Lublin: Wydawnictwo KUL, 2009).

Wypowiedź literacka a wypowiedź filozoficzna, red. Michał Głowiński, Janusz Sławiński, (Wrocław: Wydawnictwo Ossolineum, 1982).

\section{Czasopisma}

Derrida Jacques, „Ta dziwna instytucja zwana literaturą. Wywiad z Derekiem Attridge’em”, tłum. Michał P. Markowski, Literatura na świecie 11-12 (1988): 176-225.

Markowski Michał P., „Antropologia i literatura”, Teksty Drugie 6 (2007): 24-33. 
